even be that specific antenatal treatment will protect the baby from harmful antibody, as has been done with high thyroidstimulating antibody concentrations in Graves's disease corrected surgically. ${ }^{21-23}$

We are grateful to members of the AEPC for access to study records.

\section{References}

${ }^{1}$ Michaëlsson, M, and Engle, M A, Cardiovascular Clinics, 1972, 4, 86.

2 Friedman, E A, and Rutherford, J W, Obstetrics and Gynecology, 1956, 8, 601.

${ }^{3}$ Ricks, P, Obstetrics and Gynecology, 1962, 20, 36.

4 Scott, J S, Lancet, 1976, 1, 78.

${ }^{5}$ Estes, D, and Larson, D L, Clinical Obstetrics and Gynecology, 1965, 8, 307.

6 Fraga, A, et al, fournal of Rheumatology, 1974, 1, 293.

7 Grigor, R R, et al, Proceedings of the Royal Society of Medicine, 1977, 70, 99.

${ }^{8}$ Bridge, R G, and Foley, F E, American fournal of the Medical Sciences, 1954, 227, 1.

${ }^{9}$ Beck, J S, Oakley, C L, and Rowell, N R, Archives of Dermatology, 1966, 93, 656.

10 Scott, J S, Progress in Allergy, 1977, 23, 321.

11 McCue, C M, et al, Circulation, 1977, 56, 82.

12 Esscher, E, and Michaëlsson, M, in Diagnostico y Tratamiento de las Arritmias Cardiacas, ed A Bayes and J Cosin, p 618. Barcelona, Doyma, 1978.

${ }^{13} \mathrm{Lev}, \mathrm{M}$, et al, American fournal of Cardiology, 1971, 27, 481.

14 Fairfax, A J, Proceedings of the Royal Society of Medicine, 1977, 70, 327.
15 Lessof, M, British Heart fournal, 1978, 40, 211.

${ }^{16}$ Dubois, E L, reviser and editor, in Lupus Erythematosus, 2nd edn, p 270. Los Angeles, University of Southern California Press, 1976.

${ }^{17}$ Hughes, G R V, Connective Tissue Diseases, p 3. Oxford, Blackwell Scientific Publications, 1977.

${ }^{18}$ Fitzgerald, M G, Malins, J M, and O'Sullivan, D J, Lancet, 1961, 1, 1250. W

19 Bresnihan, B, et al, Lancet, 1977, 2, 1205.

20 Grennan, D M, et al, Annals of the Rheumatic Diseases, 1978, 37, 129.

${ }^{21}$ Maisey, M N, and Stimmler, L, Clinical Endocrinology, 1972, 1, 81.

${ }^{22}$ Ramsay, I, British Medical fournal, 1976, 2, 1110.

${ }^{23}$ Serup, J, and Peterson, S, Acta Obstetricia et Gynecologica Scandinavica, 1977, 56, 463.

${ }^{24}$ Hogg, G R, American fournal of Clinical Pathology, 1957, 28, 648.

25 Wright, F S, Adams, P, and Anderson, R C, American fournal of Diseases of Children, 1959, 98, 72.

26 Plant, R K, and Steven, R A, American Heart fournal, 1945, 30, 615.

27 Hull, D, Binns, B A O, and Joyce, D, Archives of Disease in Childhood, $1966,41,688$.

${ }^{28}$ Leduc, G, Marion, $\mathrm{P}$, and Davignon, A, Union Médicale du Canada, $1968,97,1029$.

29 Romano, C, et al, Minerva Pediatrica, 1975, 27, 1632.

30 Chameides, L, et al, New England Fournal of Medicine, 1977, 297, 1204.

31 Winkler, R B, Nora, A H, and Nora, J J, Circulation, 1977, 56, 1103.

32 Berube, S, et al, American fournal of Obstetrics and Gynecology, 1978, 130, 595.

${ }^{33}$ Altenburger, K M, et al, fournal of Pediatrics, 1977, 91, 618

34 Aylward, R D, British Medical fournal, 1928, 1, 943.

35 Syed, A A, Archives of Disease in Childhood, 1978, 53, 256.

${ }^{36}$ Hardy, J D, et al, Archives of Disease in Childhood, 1979, 54, 7.

\title{
Mortality in patients with haematemesis and melaena: a prospective study
}

\author{
P S HUNT, J HANSKY, M G KORMAN
}

British Medical fournal, 1979, 1, 1238-1240

\section{Summary and conclusions}

In a prospective study of death in 817 patients with haematemesis and melaena admitted on 894 occasions, the protocol included admission of all patients to a defined unit, early endoscopy and resuscitation, and planned management. Over the three consecutive twoyear periods of the study mortality significantly decreased from $9 \%$ to $2.4 \%$. Although the operative rate remained the same, the operative mortality fell from $16 \%$ to $1.6 \%$. The fall in mortality was greatest in patients with bleeding gastric ulcers.

These results suggest that prospective studies with a defined policy can influence the mortality in patients with upper gastrointestinal bleeding.

\section{Introduction}

In a retrospective study Schiller et $a l^{1}$ found that mortality in patients with upper gastrointestinal bleeding had remained constant. A pilot study at this hospital in 1971 indicated a

\footnotetext{
Gastroenterology Unit, Prince Henry's Hospital, Melbourne 3004, Victoria, Australia

P S HUNT, MS, FRACS, surgeon and senior lecturer

J HANSKY, MB, FRACP, physician and reader

M G KORMAN, FRACP, PHD, director
}

mortality of $15 \%$ in such patients. Prospective studies seem to have advantages over retrospective series because management may be simplified, complete data may be collected, and an agreed policy produces consistency in management. In October 1972 a unit with a defined management policy was established to which all patients presenting to the hospital with upper gastrointestinal bleeding were admitted. We report here the mortality from upper gastrointestinal bleeding during the past $\frac{\circ}{3}$ six years.

\section{Patients and methods}

During the six years of the study 817 patients were admitted on 894 occasions, giving a monthly admission rate of $12 \cdot 4$. Management policy was based on close liaison between the gastroenterologist, $\omega$ surgeon, and gastroenterology registrar, and defined indications were established for surgery. Patients underwent endoscopy with the forward-viewing Olympus or ACMI instrument within 12 hours after $\Phi$ admission. In all patients an intravenous line was inserted; in those? who were shocked or bleeding massively a central venous catheter was 0 inserted. The indication for blood transfusion was shock or a haemo- $O$ globin concentration of less than $10 \mathrm{~g} / \mathrm{dl}$. Admission was to a separate $\stackrel{\mathbb{\mathbb { D }}}{\mathrm{Q}}$ area in a general surgical ward but subsequently all patients with $\overrightarrow{\mathbb{D}}$ oesophageal varices requiring a Sengstaken-Blakemore tube were $\varrho$ nursed in the intensive care unit, as were all patients postoperatively.

Surgery was indicated in patients with chronic duodenal or gastric 8 ulcer surgery by recurrent bleeding, and in patients over 50 who were shocked on admission or required over 5 units of blood. In the past two years cimetidine has replaced intragastric instillation of milk and aluminium hydroxide gel as the basic treatment for acute peptic ulcer? or erosive gastritis. Continued or massive bleeding from acute peptic ulceration with a transfusion limit of 10 units was the indication for surgery in such cases. With bleeding oesophageal varices the basic 
TABLE I-Details of admissions to haematemesis and melaena unit during 1972-8 according to diagnosis

\begin{tabular}{|c|c|c|c|c|c|c|c|c|c|c|c|}
\hline & & & & \multicolumn{8}{|c|}{ Diagnosis } \\
\hline & & & & $\begin{array}{l}\text { Total No of } \\
\text { patients }\end{array}$ & $\begin{array}{l}\text { Duodenal } \\
\text { ulcer }\end{array}$ & $\begin{array}{l}\text { Erosive } \\
\text { gastritis }\end{array}$ & $\begin{array}{l}\text { Gastric } \\
\text { ulcer }\end{array}$ & Varices & $\begin{array}{l}\text { Mallory-Weiss } \\
\text { syndrome }\end{array}$ & $\begin{array}{l}\text { Other } \\
\text { causes }\end{array}$ & Undiagnosed \\
\hline $\begin{array}{l}\text { No of admissions... } \\
\text { Endoscopic diagnosis } \\
\text { No of deaths } . . \\
\text { No of operations . . } \\
\text { No of operative deaths }\end{array}$ & $\begin{array}{l}\cdots \\
\cdots \\
\because \\
\cdots \\
\cdots\end{array}$ & $\begin{array}{l}\cdots \\
\cdots \\
\cdots \\
\cdots\end{array}$ & $\begin{array}{l}\ldots \\
\cdots \\
\cdots \\
\cdots\end{array}$ & $\begin{array}{r}894 \\
720 \\
63 \\
231 \\
32\end{array}$ & $\begin{array}{r}282 \\
260 \\
13 \\
122 \\
10\end{array}$ & $\begin{array}{r}162 \\
151 \\
12 \\
17 \\
7\end{array}$ & $\begin{array}{r}98 \\
88 \\
10 \\
41 \\
7\end{array}$ & $\begin{array}{r}101 \\
95 \\
22 \\
25 \\
5\end{array}$ & $\begin{array}{r}59 \\
59 \\
1\end{array}$ & $\begin{array}{r}78 \\
67 \\
3 \\
23 \\
3\end{array}$ & 114 \\
\hline
\end{tabular}

measure used to control bleeding was tamponade with a SengstakenBlakemore tube. Further treatment was then governed by the severity of liver disease, which was assessed during the 48 hours of tamponade. The presence of one or more of jaundice, coma, ascites, and wasting classified the patient as a poor risk. In these patients the balloon was usually reinflated and a transfusion limit of 8 units of blood set. Rebleeding in patients considered to be a good risk was controlled by balloon tamponade and later treated by portal-systemic shunting. During the last three years of the study a standard end-to-side portacaval shunt was the procedure of choice.

Every patient was discussed at weekly gastroenterology meetings. Making this protocol known within the hospital and giving sixmonthly progress reports was considered to be an important part of the unit's activities. Patients remained under the care of the unit for their entire hospital stay, either until there was no evidence of further bleeding and they were well enough for discharge or until they had fully recovered after surgery.

The statistical method used was the $\chi^{2}$ comparison of the pooled results for 1972-6 with those for 1976-8, with one degree of freedom.

\section{Results}

Altogether 817 patients were admitted to the unit on 894 occasions (627 men, 267 women). The age range was 17-91 years. Sixty-three deaths occurred in the hospital during the six years, giving an admission mortality of $7 \%$ and a patient mortality of $8 \%$. Table I shows the rate of endoscopic diagnosis, mortality, operative rate, and operative mortality for the various conditions. Endoscopy was accurate in $95 \%$ of the cases in which it was carried out. Altogether 231 operations were performed, an operative rate of $26 \%$. Thirty-two paticnts died at opcration (operative mortality $14 \%$ ). On admission 174 patients had significant cardiopulmonary disease and 36 had active malignart discase.

\section{TRENDS IN CLINICAL EXPERIENCE AND MORTALITY}

To evaluate trends we compared the three two-year periods of the study (table II). During 1972-4 there were 307 admissions and 27 deaths, a mortality of $9 \%$; during 1974-6, 337 admissions and 30 deaths, a mortality of $9 \%$; and during 1976-8, 250 admissions and six deaths, a mortality of $2 \cdot 4 \%$. Thus a significant reduction in mortality occurred in the final two years of the study when compared with the first four years $\left(\chi^{2}=12 \cdot 4, \mathrm{P}<0 \cdot 0005\right)$. The rate of endoscopic diagnosis significantly improved from $66 \%$ in $1972-4$ to $84 \%$ in $1974-6$ and $93 \%$ in $1976-8\left(\chi^{2}=30.2, P<0.0005\right)$. Operative mortality fell significantly from $16 \%$ and $20 \%$ in the first and second two-year periods respectively to $1.6 \%$ in the final two years $\left(\chi^{2}=11.5, \mathrm{P}<0.001\right)$ although the operative rate was similar throughout the study.

Table III shows the trend in disease incidence and death rate for each two-year period. The fall in numbers for the final two years was

TABLE II-Trend in results over three consecutive two-year periods

1972-4 1974-6 1976-8 Significance*

No of admissions

Endoscopic diagnosis

No of deaths

No of operations

$\begin{array}{rrrl}307 & 337 & 250 & \\ 202 & 285 & 233 & \mathrm{P}<0.0005 \\ 27 & 30 & 6 & \mathrm{P}<0.0005 \\ 73 & 95 & 63 & \mathrm{NS} \\ 12 & 19 & 1 & \mathrm{P}<0.001\end{array}$

*Results for 1976-8 compared with those for 1972-6.

NS $=$ Not significant. partly accounted for by a decrease in the number of patients admitted with acute peptic ulceration or erosive gastritis $\left(\chi^{2}=6.3, P<0.025\right)$. There was a small but steady increase in the number of admissions for bleeding gastric ulcer. The operative rate for acute peptic ulceration and duodenal ulcer fell, though not significantly. Although mortality fell in all groups in the final two years, only in the patients with

TABLE III-Trend in mortality during 1972-8 according to cause of haematemesis and melaena

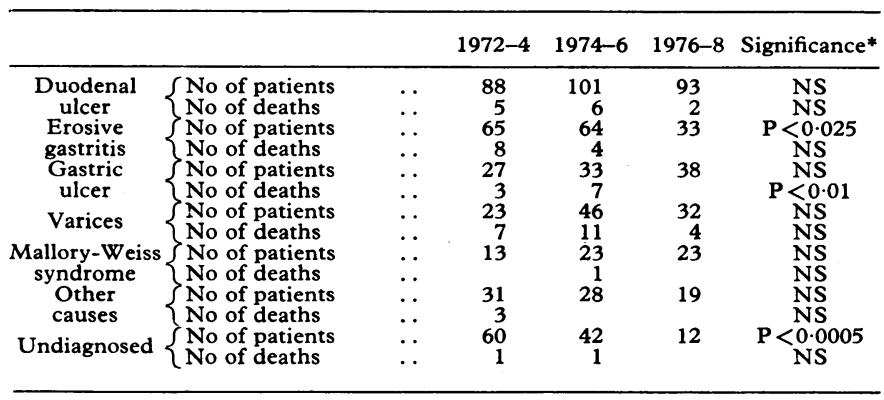

*Results for 1976-8 compared with those for 1972-6.

NS $=$ Not significant.

gastric ulcer did this reach significance $\left(\chi^{2}=7 \cdot 7, \mathrm{P}<0.01\right)$. The appreciable reduction in the number of patients whose condition was undiagnosed reflects the improvement in the rate of endoscopic diagnosis $\left(\gamma^{2}=19.9, P<0.0005\right)$. There was no significant difference between the consecutive two-year periods in the incidence of shock, blood requirements, and proportion of anaemic patients.

\section{Discussion}

This prospective study of all patients admitted with haematemesis and melaena to an inner-city teaching hospital showed a significant reduction in mortality from $9 \%$ in the first four years to $2.4 \%$ in the final two years. It has been suggested that mortality in this condition has been stable during the past 20 or so years. ${ }^{2}$ Studies in Britain ${ }^{1}$ and Australia ${ }^{2}$ have shown mortality rates of $9-12 \%$ during this period, although a recent retrospective study over 12 months disclosed a mortality of $5 \% .^{3}$

It is difficult both to make comparisons between countries and to interpret the results of retrospective studies. Not only are the data sometimes incomplete but many series either exclude or include too few patients with bleeding oesophageal varices, the major cause of death in cases of upper gastrointestinal bleeding. For example, the widely quoted study of Schiller $e t a l^{1}$ cannot be readily applied to Australian conditions because of its low incidence of varices of $2.5 \%$, compared with our incidence of $11 \%$. Their overall mortality rate was $9 \%$, but when deaths due to varices are excluded our mortality rate approached $5 \%$ over the six-year period.

Interestingly, fewer patients were admitted with a diagnosis of acute peptic ulceration while the number of patients with other diagnoses remained stable. The reason for this is not apparent, and we await results from other institutions to see whether this 
fall is peculiar to our population. Himal et $a l^{4}$ recently reported a similar decrease in Montreal in the number of patients with acute peptic ulceration secondary to ulcerogenic drugs.

Analysis of our figures over the past year has shown one death in 107 admissions, a mortality rate of under $1 \%$. We believe that our improved results are due to several factors, ranging from early diagnosis and vigorous resuscitation to strict criteria for surgical intervention. Possibly the most important factor has been the formation of a unit with a combined medical and surgical approach in which patients are cared for by the same personnel familiar with all aspects of upper gastrointestinal haemorrhage.

We therefore conclude that a prospective system of management with regular review of results and formation of a unit certainly improve mortality rate in patients with upper gastrointestinal bleeding.

We wish to thank Sister A Stewardson for her help with data collection, and Ms E Kaminski for her valuable secretarial work.

\section{References}

1 Schiller, K F R, Truelove, S C, and Williams, D G, British Medical fournal, 1970, 2, 7.

2 Medical fournal of Australia, 1973, 2, 256.

3 Paull, A, Vandeth, A G, and Grant, A K, Australian and New Zealand Fournal of Medicine, 1974, 4, 12.

${ }^{4}$ Himal, H S, Perrault, C, and Mzabi, R, Surgery, 1978, 84, 448.

(Accepted 20 March 1979)

\title{
Extradural haematoma: effect of delayed treatment
}

\author{
A D MENDELOW，M Z KARMI，K S PAUL，G A G FULLER，F J GILLINGHAM
}

British Medical fournal, 1979, 1, 1240-1242

\section{Summary and conclusions}

The case records of patients with extradural haematomas treated in the Lothian region during 1951-60 and 1968-77 were analysed to assess the effect of delay in treatment on morbidity and mortality. Delay was defined as the time from deterioration in level of consciousness to surgical evacuation of clot. There were 83 supratentorial extradural haematomas unassociated with intradural clot or contusion. The mean delay in patients who died was 15.7 hours, while in good-quality survivors the mean delay was 1.9 hours. Mortality decreased from $33.3 \%$ during 1951-60 to 8.9\% during 1968-77. In addition, good recovery without morbidity occurred in $40.7 \%$ of patients in the earlier period and $67.9 \%$ in the later period. Mean delays from deterioration in level of consciousness to operation were 9.8 and 2.4 hours in the earlier and later periods respectively.

The results emphasise the need for immediate operation in patients deteriorating with extradural haematomas. Direct admission of all head-injured patients to a head and spinal injuries unit staffed by neurosurgeons resulted in minimal delay times as well as a reduction in morbidity and mortality.

\section{Introduction}

Delay in removing expanding intracranial haematomas is an important factor contributing to increased morbidity and mortality in head injuries, and this is particularly so with extradural haematomas. ${ }^{12}$ The effect of delay on outcome in cases of extradural haematoma, however, has not been measured. This is particularly important now that frequent use of the CAT scan is being recommended in head injuries ${ }^{3}$ because unnecessary delays in its use may occur when there is a clear-cut clinical

Head and Spinal Injuries Unit, Department of Surgical Neurology, Royal Infirmary, Edinburgh EH3 9YW

A D MENDELOW, PHD, FRCS, registrar

M Z KARMI, FRCS, registrar

K S PAUL, MS, registrar

G A G FULLER, FRCS, registrar

F J GILLINGHAM, FRCS, FRCPED, professor and head of department

indication for immediate operation. Furthermore, knowing the time that can be spared for such investigation and transferring patients with head injuries may aid the planning and organisation of neurosurgical services. In the Lothian region before 1960 (the first decade studied here) head-injured patients were admitted to general surgical beds, and after that time (second decade studied) they were admitted direct to the head and spinal injuries unit under the care of neurosurgeons. To assess the effect this has had on outcome in patients with extradural haematomas we have compared the results obtained during the decades 1951-60 and 1968-77.

\section{Patients and methods}

We examined the case records of all patients with extradural haematomas treated in the Edinburgh area during 1951-60 and 1968-77. An extradural haematoma was considered to be significant when thicker than $1.5 \mathrm{~cm}$. Small haematomas associated with depressed fractures of the skull were excluded. Particular attention was paid to time relations, which were obtained from the records as well as operating-theatre books, anaesthetic charts, nursing records, and admission books. Delay was defined as the time from the first recorded deterioration in level of consciousness to operation. Delays were recorded as delay in hospital and total delay, some patients having deteriorated before admission. Delay in hospital thus represents that part of the total delay that occurred either in the department of surgical neurology or in other wards in the same hospital but after a neurosurgical opinion was available or had been requested, or both. Such delays occurred before a neurosurgical admission ward was established at the Edinburgh Royal Infirmary for admission of all head injuries.

Lucid interval was defined as the time from the injury or recovery from initial unconsciousness, whichever was the shorter, to subsequent deterioration in consciousness. Results were classified according to outcome at the last available assessment and graded as follows: O, full social and economic independence; $\mathrm{A}$, slightly disabled; $\mathrm{B}$, disabled but independent; $C$, disabled and dependent; $D$, death.

Statistics-Delay times are expressed as means $\pm S E$ of mean. Mean values were compared with use of Wilcoxon's rank sum test. ${ }^{4}$ Numerical results were compared by $\chi^{2}$ analysis. ${ }^{5} \mathrm{~A}$ significant difference was accepted when $\mathrm{P}<0.05$.

\section{Results}

Out of 145 patients with a significant extradural haematoma, 50 had an associated intradural haematoma or contusion determined radiologically, at operation, or at necropsy. In seven of the remaining $95 \stackrel{\rightleftharpoons}{\rightleftharpoons}$ cases we could not obtain all the relevant time relations, and in a further five the extradural haematoma lay within the posterior fossa. There were thus 83 pure supratentorial extradural haematomas un- 